\title{
Concept of the exhaust system of combustion engines used in underground mining
}

Analyses the problems occurring in the exploitation combustion engines used in mining have been presented in article. Design solutions used at present to protect the intake and exhaust systems of internal combustion engines operated in underground hard coal mines have been also described. A new design concept of exhaust system have been presented.

Key words: exhaust system, temperature of exhaust gases, CI combustion engine, flame arrester, hard coal mining

\section{Introduction}

The use of internal combustion engines in underground mining, and especially in hard coal mining, requires meeting a number of safety requirements. Safety requirements related to the use of internal combustion engines in potentially explosive atmospheres are described in a series of Standards EN 1834.

The article focuses on the requirements for Group I engines used in underground workings susceptible to methane firedamp and/or combustible dust (EN 1834-2: 2000 [1]) as regards the protection of the air intake and exhaust systems.

The main requirement for air intake and exhaust systems is a necessity of equipping them with the flame arrester, and additionally equipping the exhaust system with spark arrester. Another requirement for machines working in the presence of combustible dust is keeping the surface temperature below $150^{\circ} \mathrm{C}$. The maximum temperature applies to the surface of the machine as well as to the exhaust gases emitted into the atmosphere directly behind the flame arrester.

Therefore, design solutions of flame arresters and the method of reducing the exhaust gases temperature to the required value are of vital importance.

An additional aspect that is particularly important in underground mine workings is the quality of emitted exhaust gases. Specific requirements in this regard depend on engine power and are described in the Standard EN 16791:1998+A1:2011 [2]. Table 1 shows the requirements of the Standard in terms of the emission limit applied to engines operating underground.

Table 1. Emission limits [2]

\begin{tabular}{|l|c|c|c|c|}
\hline $\begin{array}{l}\text { Power } \\
\mathrm{P}[\mathrm{kW}]\end{array}$ & $\begin{array}{c}\text { Carbon } \\
\text { monoxide } \\
\mathrm{CO} \\
{[\mathrm{g} / \mathrm{kWh}]}\end{array}$ & $\begin{array}{c}\text { Hydrocarbons } \\
\text { HC }[\mathrm{g} / \mathrm{kWh}]\end{array}$ & $\begin{array}{c}\text { Nitrogenoxide } \\
\text { NOx [g/kWh] }\end{array}$ & $\begin{array}{c}\text { Particulates } \\
\text { PT } \\
{[\mathrm{g} / \mathrm{kWh}]}\end{array}$ \\
\hline $\begin{array}{l}37 \leq \mathrm{P} \\
<75\end{array}$ & 6.5 & 1.3 & 9.2 & 0.85 \\
\hline $\begin{array}{l}75 \leq \mathrm{P} \\
<130\end{array}$ & 5.0 & 1.3 & 9.2 & 0.7 \\
\hline $\begin{array}{l}130 \leq \mathrm{P} \\
<560\end{array}$ & 5.0 & 1.3 & 9.2 & 0.54 \\
\hline
\end{tabular}

Although internal combustion engines currently used in underground workings machines meet the above requirements, due to the limited cross-section, limited volume of mining workings and the health of mining personnel, any improvement in exhaust gas quality is justified.

\section{Present solutions}

\subsection{Flame arresters}

Flame arresters are designed to stop the flame that may occur in the intake and/or exhaust system before igniting the potentially explosive external atmosphere.

Extinguishing the flame can be achieved by eliminating one of the following components: fuel, oxygen, heat. Flame arresters eliminate heat and their principle of operation is based on gap effect (flame extinguishing in narrow gap through absorbed heat from a flame, below auto-ignition temperature). The gap effect is closely associated with Maximum Experimental Safe Gap (MESG). MESG is the result of standard measurement, described in the EN 6007920-1:2010 Standard [3], aimed at determining the maximum gap at the standard length of $25 \mathrm{~mm}$ (and on the standard stand) that does not cause explosion transfer (it extinguishes the flame). Gases and vapors are classified according to their maximum experimental safe gaps into Groups I, IIA, IIB and IIC.

Group I includes equipment for mines susceptible to firedamp (MESG Methane (firedamp) = 1.14). Group II includes equipment for areas with an explosive gas atmosphere other than mines susceptible to firedamp. Group II equipment is subdivided and, for the purpose of classification of gases and vapors, the MESG limits are [3]:

- Group IIA: MESG $\geq 0.9 \mathrm{~mm}$ (exemplary gases: propane, acetone),

- Group IIB: $0.5 \mathrm{~mm}<\mathrm{MESG}<0.9 \mathrm{~mm}$ (exemplary gases: ethylene, formaldehyde),

- Group IIC: MESG $\leq 0.5 \mathrm{~mm}$ (exemplary gases: hydrogen, acetylene).

\subsection{Examples of flame arresters}

There are many manufacturers offering flame arresters of various types (end tubes, deflagration, detonation, etc.), certified for use in Group II Hazardous Areas. A typical function element (flame extinguishing) is shown in Fig. 1.

Important parameters for the proper operation of the flame arrester are the gap width, its length (thickness of the function element) and maximum working temperature (maximum working temperature is related to the possibility of absorbing heat from a flame, below the auto-ignition temperature). 

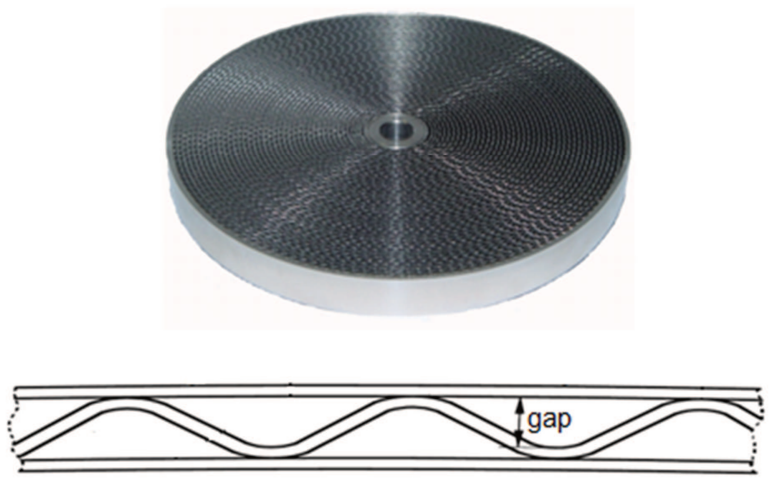

Fig. 1. Example of function element of a flame arrester [4]

There are no certified flame arresters for Group I (intended for an operation in underground mines).

Type tests of such flame arresters include testing of the whole "installation", from the flame arrester in the air inlet system to the flame arrester in the exhaust system. The requirements and the type approval process are described in EN 1834-2: 2010 Standard (for use in internal combustion engines). An example of the flame arrester, designed at the KOMAG Institute of Mining Technology, used in a mine combustion engine is shown in Fig. 2 and its functional element is shown in Fig. 3.

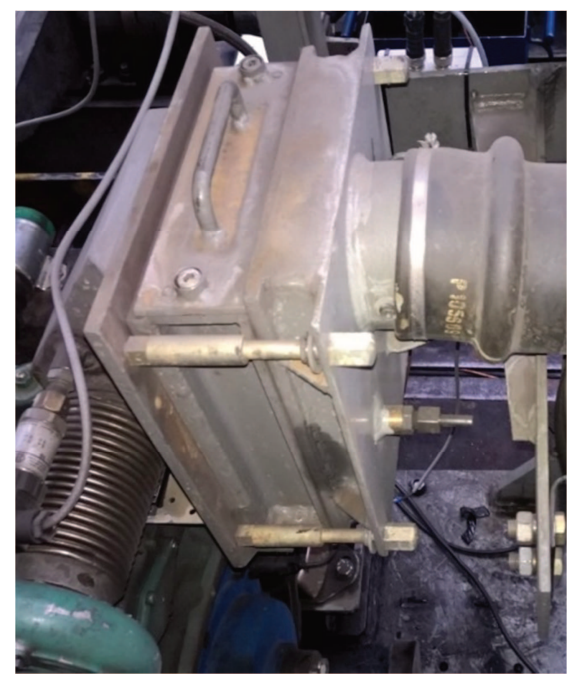

Fig. 2. Flame arrester used in a mine combustion engine
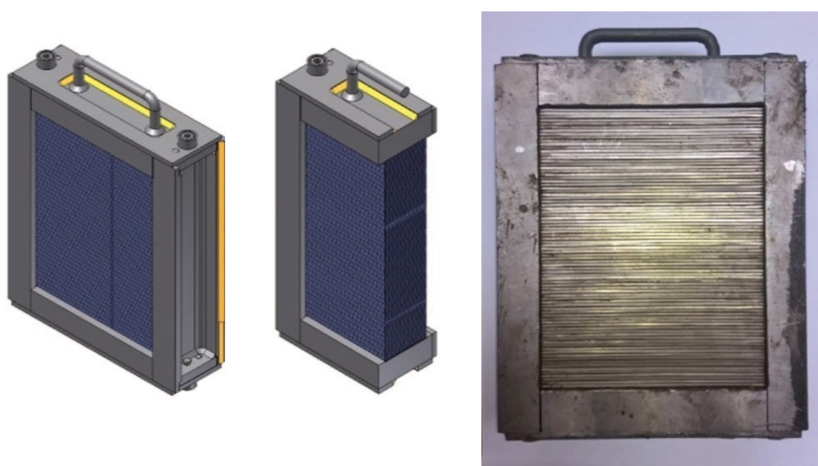

Fig. 3. Function element of a flame arrester, model (left), real view ( right) [5]

\subsection{Reduction of exhaust gas temperature}

In accordance with the requirements of EN 1834-2 Standard, the exhaust gas temperature from the engine, in the presence of combustible dust in the atmosphere, measured directly behind the flame arrester cannot exceed $150^{\circ} \mathrm{C}$. Two types of heat exchangers, used to reduce exhaust gas temperature to the required values, can be installed in the internal combustion engines. They include a wet heat exchanger (also called water washer) and a dry heat exchanger. In the first solution, the exhaust gas has direct contact with the coolant. In the second solution, the transmission of heat from the exhaust gases to the coolant is carried out through the walls separating the exhaust gas from the coolant [5]. So far the research and development work realized at the KOMAG Institute of Mining Technology has included both technical solutions (Figs 4 to 7).

Despite high efficiency of exhaust gas cooling with the use of wet heat exchanger, the disadvantage of using it consists in a necessity of monitoring the level of the cooling water and of making it up. As a consequence, dry heat exchangers are used more often. In a dry heat exchanger the coolant circulates in a closed loop system and after getting the heat from the exhaust gases it is cooled by an additional radiator with a forced air flow[6] .

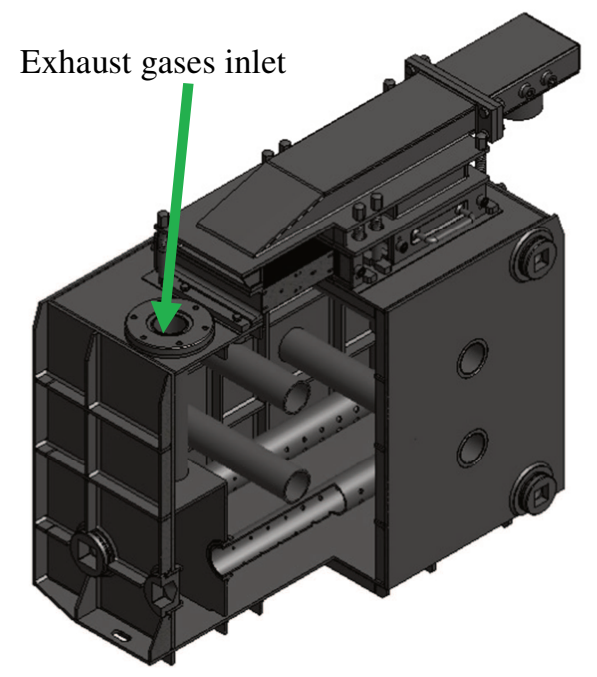

Fig. 4. Wet heat exchanger (model) [6]

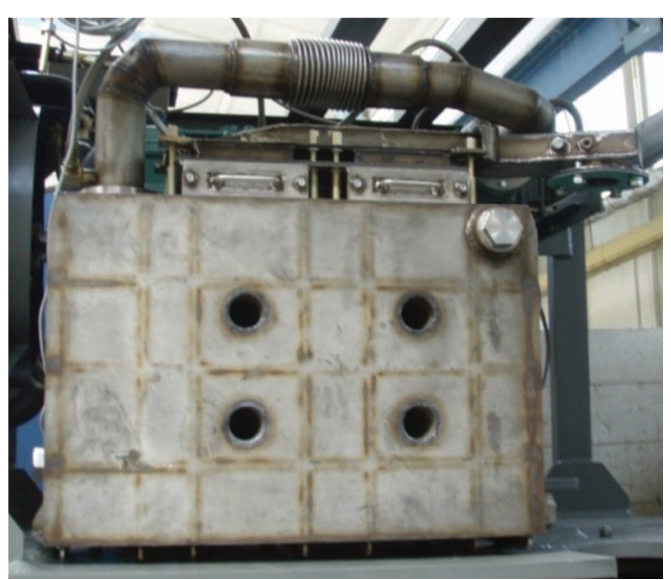

Fig. 5. Wet heat exchanger (real view) [6] 


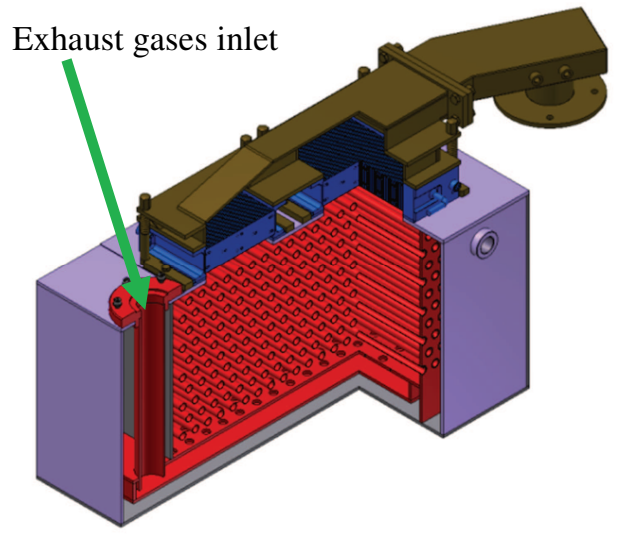

Fig. 6. Dry heat exchanger (model) [7]

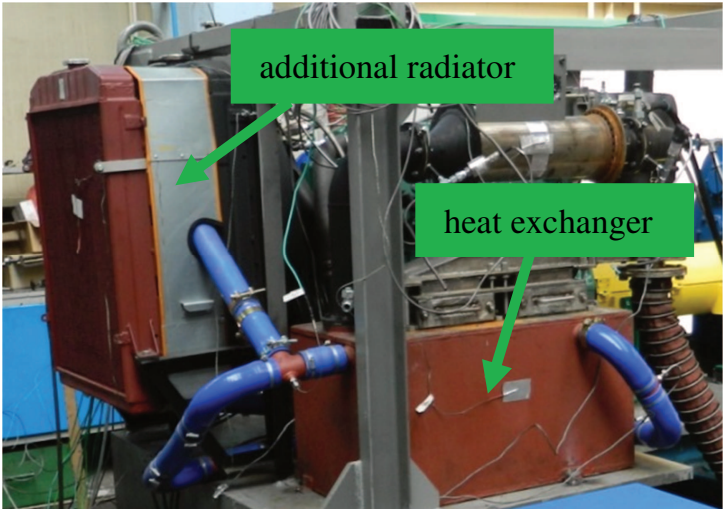

Fig. 7. Dry heat exchanger (real view) [7]

\section{Concepts of the exhaust system and function element of the flame arrester}

One of the basic disadvantages of cooling systems, used at present, is their big weight and dimensions. Additionally the wet heat exchanger requires constant monitoring of the level of the coolant as well as it gives additional resistance to the exhaust gases.

In order to improve the exhaust system, and at the same time to meet the safety requirements for combustion engines working in the hard coal mining industry, and with a purpose to improve exhaust gas quality, the authors have developed a new design concept of this system. A general view of the design concept is shown in Fig. 8.

In the presented design concept combustion products from the internal combustion engine are directed to the Diesel Oxidation Catalyst (DOC), where $\mathrm{CO}$ and $\mathrm{HC}$ oxidation occurs. The DOC reactor (in addition to air thermal insulation) is provided with a solid insulation (eg. mineral wool) to maintain its surface temperature below $150{ }^{\circ} \mathrm{C}$ (additional water cooling may be provided if necessary). To increase the oxidation, additional air (oxygen) is supplied before the catalytic reactor. The exhaust gas is cooled using compressed air from the environment. Mixing of cool air with hot exhaust gases is realized with an ejector. The control system, using temperature transducers, acts as a protection against excessive exhaust gas temperature and oxidation control in the DOC reactor (control of the amount of oxygen directed to the reactor input is considered). The use of pressure transducers in the intake air system for the engine is aimed at an early detection of the risk associated with the transfer of the explosion through the intake air system.

As a compressor providing additional air, the use of a second compressor powered by exhaust gases or a compressor powered by an autonomous source (eg. hydraulic drive) is considered.

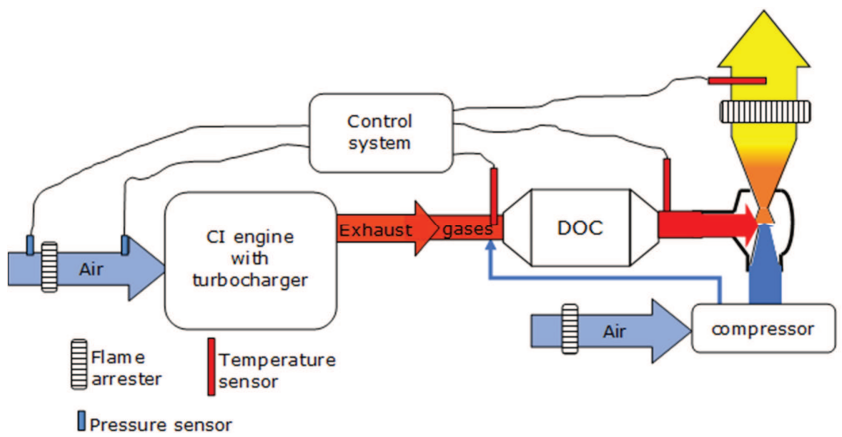

Fig. 8. Design concept of air cooling of exhaust gases with DOC reactor [8]

As a part of the planned research work on a development of the presented concept, an analysis of possibilities to use ceramic catalyst monoliths instead of currently used function element in flame arrester is also made. The ability to use such cores would be an alternative to the solutions used at present.

\section{Summary}

The article describes design solutions used at present to protect the intake and exhaust systems of internal combustion engines operated in underground hard coal mines. Special attention is paid to the risks resulting from high temperature and the transfer of flame. From the presented analyses the following conclusions can be drawn:

- Group IIA: MESG $\geq 0.9 \mathrm{~mm}$ (exemplary gases: propane, acetone),

- exhaust gas temperature reduction systems, used at present, are of large dimensions and weight,

- the wet heat exchanger requires constant monitoring of the coolant level, which is a hindrance in the day-to-day operation of machines,

- the wet heat exchanger is characterized by high resistance to exhaust gases,

- the dry heat exchanger does not require water replenishment for daily use,

- the dry heat exchanger requires an additional radiator and a pump for water circulation, in order to decrease the temperature of water.

This article presents the concept of the exhaust system.

The expected benefits of this concept include:

- significant decrease of $\mathrm{CO}$ and $\mathrm{HC}$ content in exhaust gases $(>50 \%)$ [9],

- elimination of the heat exchanger,

- weight reduction of the entire exhaust system,

- increase of efficiency (by reducing weight in comparison with the systems used at present) and of engine power (reduction of exhaust resistance).

However, the disadvantages are as follows:

- possibility of increasing $\mathrm{NO}_{\mathrm{x}}$ emissions,

- additional equipment, i.e. the second air compressor and another flame arrester. 
As a part of the development work on the concept, numerical analyses are planned to determine the technical parameters of the compressor used for cooling the exhaust gases and the ejector element. As a part of the research work on the possible use of ceramic monoliths, the first step includes testing the abrasion resistance of ceramic material which, according to the requirements of EN 1834-2: 2002 Standard, must be equal to or better than for stainless steel 14404 or 14435 .

\section{Bibliography}

[1] EN 1834-2:2000 Reciprocating internal combustion engines. Safety requirements for design and construction of engines for use in potentially explosive atmospheres. Group I engines for use in underground workings susceptible to firedamp and/or combustible dust.

[2] EN 1679-1:1998+A1:2011 Reciprocating internal combustion engines. Safety. Compression ignition engines.

[3] EN 60079-20-1:2010 Explosive atmospheres. Material characteristics for gas and vapour classification. Test methods and data.

[4] www.techmako.pl, Przerywacze płomieni/Zawory oddechowe

[5] KACZMARCZYK K., BRZEŻAŃSKI, M. Problemy ekologiczne silników spalinowych eksploatowanych w wyrobi-

Marek Brzeżański, DSc., DEng. - Faculty of Mechanical Engineering at Cracow University of Technology.

e-mail:MBrzez@pk.edu.pl skach podziemnych węgla kamiennego Prace naukowe Monografie. Gliwice. 2015.

[6] DOBRZANIECKI, P. Modelowanie charakterystyk trakcyjnych napędów na przykładzie pojazdów górnictwa węglowego. Praca doktorska. Gliwice 2012.

[7] KACZMARCZYK, K. Metoda dostosowania silnika do wymagań stawianych górniczym napędom spalinowym. Praca doktorska. Gliwice 2014.

[8] LESIAK, K. Redukcja toksycznych składników w spalinach silników wysokoprężnych oraz optymalizacja układu wylotowego spalin. ITG KOMAG, Gliwice 2016, materiały niepublikowane.

[9] KRUCZYŃSKI, S., DANILCZYK, W. Ograniczanie szkodliwości gazów wylotowych silników spalinowych poprzez zastosowanie reaktorów katalitycznych. MOTROL. 2007, 9, 93-102.

Krzysztof Lesiak, MEng. - KOMAG Institute of Mining Technology.

e-mail: KLesiak@komag.eu 